\title{
London's Rise as an Offshore RMB Financial Centre: State-Finance Relations and Selective Institutional Adaptation
}

Laura-Marie Töpfer and Sarah Hall ${ }^{1}$

Smith School of Enterprise and the Environment, University of Oxford, Oxford OX13QY, UK. Email: Laura-Marie.Topfer@ouce.ox.ac.uk

${ }^{1}$ Corresponding author

School of Geography

University of Nottingham

Nottingham UK

NG7 2RD

Sarah.hall@,nottingham.ac.uk

December 2016

Paper accepted for publication in Regional Studies, 8 December 2016 


\section{Introduction}

“Great powers have great currencies.” Robert Mundell (1993)

With China's emergence as a major economic power, the Renminbi (RMB) has become increasingly important in global financial markets. Whilst the RMB had no international influence in the early 2000 s, it is now the fifth most-used currency for international payments and part of the International Monetary Fund's basket of global reserve currencies (IMF, 2015). The main policy channel facilitating this growing use of RMB is the Renminbi Qualified Foreign Institutional Investor (RQFII) scheme established in 2011. This approval system permits foreign investors to invest offshore RMB raised in designated international financial centres (IFCs) into Chinese securities for the first time. The geographical expansion of the RQFII scheme is increasingly giving global investors alternatives to the US dollar as the dominant currency. The internationalisation of the RMB, and the rise of state capitalism underpinning this development, therefore fundamentally challenges how we think about the distribution of power in the international financial system.

These shifts in financial power are beginning to reshape established IFC hierarchies. Securing early approval from the Chinese government under the RQFII scheme equips IFCs with a competitive advantage over their rivals. It provides the exclusive right to use RMB offshore for trade, settlement and RMB-denominated assets, and thus increases the attractiveness of an IFC for global investors. Furthermore, once Chinese capital markets are fully liberalised, the total number of RQFII hubs will surge. Early approval allows more time to develop expertise in RMB products and integrate them into existing financial structures. IFCs with an established track record in RMB finance are then more likely to retain the confidence of global investors. This suggests that the Chinese government directly affects the distribution of power between IFCs, by granting early RQFII approval to some centres but excluding others. Understanding the dynamics behind the development of offshore RMB 
centres is therefore critical to explain IFC competition in the decade ahead. Yet, empirical research on this topic remains scarce.

We address this empirical gap in the literature, by investigating how the interplay between state and private interests has shaped London's development as an offshore RMB centre. London was the first foreign ${ }^{\mathrm{ii}}$ RQFII hub to be approved by the Chinese government in 2013. The subsequent development of London's infrastructure to access and process RMB payment flows has, however, lagged behind other RQFII hubs. Money centres such as Singapore have now overtaken London in terms of allocated RQFII quota and RMB trading volumes (SWIFT, 2014). This study seeks to analyse the drivers behind this shift and explain the uneven development of London's offshore RMB hub. Understanding this U-turn in London's RQFII experience from first-mover to relative laggard provides important insights into why some RMB trading centres succeed, whereas others fall behind their competition. The UK's recent 'Brexit' vote makes these insights particular timely, by providing a foundation for understanding how London's appeal as the leading RMB gateway to European markets evolves in the future.

To investigate this puzzle, we draw on an original dataset of 121 multi-stakeholder interviews conducted in London and China's main financial and political centres: Shanghai, Beijing, Hong Kong and Shenzhen. This dataset covers the year in which London's RMB centre was created and its subsequent development. This enabled us to adopt a longitudinal approach, by tracing the coevolution of state and private sector interests across time and space. Interviews were then verified against Chinese and UK government documents and financial news sources. Such data triangulation allowed for constructing a nuanced account of how state-private tensions shape the selective absorption of RMB finance into London's financial architecture.

This empirical analysis makes an important conceptual intervention, by extending politically sensitive readings of the international financial system (Agnew 2009, 2012; Eichengreen, 2012; Cohen, 2015). London's development as an offshore RMB centre demonstrates the need to examine 
what Agnew (2009) terms transnational 'money games': It is the relationship between finance and state power, both within and outside state jurisdictions, that is central to understanding global finance. We take this work as our conceptual starting point to examine the development of RMB finance in London. Our analysis borrows from organisational sociology on 'mimetic isomorphism' (DiMaggio and Powell 1983) and its applications to global finance (Djelic and Quack 2007; Bassens et al 2013). These works examine how seemingly 'universal' economic practices require context-specific adaptation when entering new institutional landscapes. They emphasise how companies tend to replicate organisational 'best practice' of a recognised lead firm, with the aim of ultimately supplanting the leader. Whilst these insights are instructive for our discussion on institutional adaptation, the notion of mimicking an acknowledged leader does not apply in this case. As the first foreign RMB centre established outside China ${ }^{\mathrm{iii}}$, London constitutes new testing ground for how RMB finance adapts to Western institutional contexts. Consequently, there is no proven 'best practice' to follow. It is in this context of uncertainty that our analysis of London's RMB centre becomes important for advancing existing explanations of institutional adaptation.

This paper makes several important contributions to literatures on IFCs and state-finance relations. It challenges the view within the political economy literature that financial globalisation ${ }^{\text {iv }}$ has led to the retreat of the state (Büthe and Mattli, 2011). Following the work of Agnew (2009, 2012), we propose an alternative reading of the state that emphasises its active role as a financial market architect. By investigating the case of London, it is demonstrated that the development of offshore RMB centres is best understood as selective adaptation. What makes London's adaptation to RMB finance 'selective' is the shift in state-private bargaining dynamics from strategic alignment toward an increasing bifurcation of interests. This study therefore adds to our understanding of which features reflect mimicry of 'universal' practices and which are 'context-specific' in the development of new financial product markets (Bassens et al, 2013). 
There has also been renewed interest among social scientists in offshore financial space following the 2008 global financial crisis. Recent works have emphasised legal features such as entire offshore jurisdictions in attracting offshore financial activity (Clark et al, 2015; Wainwright, 2011). This study extends these insights, by highlighting the need to politicise the analysis of offshore finance. It seeks to broaden our understanding of the role played by the state beyond conventional regulatory functions: Governments not only act as regulators or stabilisers of offshore financial space; they actively create it.

This paper unfolds in four parts. The first part outlines the paper's conceptual premises grounded in economic geographic theory. The second part presents the dataset and methodology. The third part discusses the empirical findings. It first contextualises the geographical distribution of offshore RMB centres, by teasing out the political drivers behind the creation of the first foreign RMB centre in London. Subsequently, changes in state-private interests are analysed and how these affect the integration of RMB finance into London's IFC architecture. The paper concludes, by summarising the results and outlining implications for policy and future research.

\section{Conceptualising Institutional Adaptation in Offshore RMB Centres}

The development of and relations between financial centres have commonly been explored through the conceptual lens of location-specific complementarities (Clark, 2002; Faulconbridge, 2004) and shared commonalities that facilitate collaboration between centre-specific institutions ${ }^{\mathrm{v}}$ (Wójcik, 2013). This has led to a focus on structural explanations including legal frameworks, political systems, labour flows and cultural norms (Hall, 2010). Within this literature, most research highlights the relationships between Western IFCs such as the 'New York-London axis' (Wójcik, 2013) and London-Frankfurt relations (Beaverstock et al, 2005). This has led to a focus on explaining institutional stability over institutional change, whereas questions of politics and power have been 
sidelined, especially in non-Western contexts.

To bring the IFC literature into closer dialogue with the politics of change in Chinese finance, we combine insights from political geography and political economy on global finance. Political geographers emphasise the role of the state in shaping the spatial underpinnings of different currency regimes (Agnew 2009; Cohen 2011). Accordingly, the transition of currencies from a nationally confined status toward transnational or reserve currency status is shaped by the strategic motivations behind governments' 'money games' and the political-economic circumstances in which they are embedded (Agnew 2012). We apply these insights to the largely unexplored field of RMB centres, by exploring how state-private relations shape their development.

For this purpose, the emphasis on government incentives in political geography is coupled with insights on political bargaining in Chinese political economy and China area studies. This literature tends to focus on the role of firm-government bargaining in regional development (Hu and Lin, 2013) including foreign direct investment policies (Wei, 2015), notably in industrial sectors such as Chinese car manufacturing (Chin, 2010, Oh, 2013). What unites these works is their emphasis on interdependent bargaining between Chinese political elites, vested domestic interests and foreign investors to explain economic outcomes.

With a few notable exceptions (Chen et al, 2015; Töpfer, 2015), the area of indirect foreign investments ${ }^{\mathrm{vi}}$ has, however, been less frequently studied. This paper adds to this growing body of research, by extending the conceptual premises of interdependent bargaining beyond the firmgovernment nexus and applying them to government-IFC relations. We conceptualise the development of offshore RMB centres as a bargaining outcome between the Chinese government and financial sector and state agents operating within an RQFII-licensed IFC. Rather than concentrating on self-reinforcing complementarities, the main premise is that agents will seek to change institutional features of RMB centres if they no longer satisfy their interests. This echoes the emphasis on conscious political choices in political geography and is the defining feature of what we 
term 'selective adaptation'. We posit that the adaptation of established IFC architectures to RMB finance becomes 'selective' if state-private sector bargaining shifts from strategic alignment toward a bifurcation of interests. Such changes can be triggered by external shocks such as financial crises, or due to gradual learning effects that may alter agent preferences (Hall and Thelen, 2009). This focus on political bargaining dynamics provides a useful heuristic for examining how adaptation occurs in situations of uncertainty when no 'best practice' template exists for agents to follow. This responds to calls for examining how agency shapes financial geographies (Coe et al, 2014) and adds to the literature on institutional isomorphism (Di Maggio and Powell, 1983; Bassens et al, 2013).

Analysing offshore RMB centres also requires conceptualising 'offshore finance'. Based on the global financial networks literature (Coe et al, 2014), recent works have conceptualised places of offshore finance as 'any jurisdiction through which financial claims pass to avoid policy constraints elsewhere' (Kurdle, 2013:2). Applying this definition to the analysis of RMB centres clarifies that offshore finance is not about any type of financial services; it is about the booking of financial claims, also known as financial instruments or assets (Clark et al, 2015). For example, if a UK company holding RQFII quota issued in London provides advice on RMB investments to an American company without RQFII quota, this is not treated as offshore finance ${ }^{\mathrm{vii}}$. However, if the same UK firm sold some of its own RQFII quota to the American company for RMB market access, then this would count as offshore finance.

Equating places of offshore finance with 'jurisdictions' nonetheless risks downplaying the role of the state. The global expansion of RMB centres is not driven by the ability of their legal system to 'avoid policy constraints', as Kurdle's definition suggests. It serves the purpose of satisfying the Chinese government's strategic objectives to promote the more widespread use of RMB in international transactions. This suggests that the legal emphasis in 'offshore jurisdictions' is not sufficient to capture the political underpinnings in offshore RMB finance. Recent works have acknowledged that governments are important agents in offshore finance, as they devise national and 
international laws and even create new places of offshore finance (Clark et al, 2015). This paper extends these works on IFC 'offshore jurisdictions', by specifying how state-firm bargaining shapes their development.

\section{Data and Methods}

Grounded in new economic geography research, the main objective of this study is to trace the evolution of London's offshore RMB hub. The City's RMB market covers various financial activities. These include foreign exchange trading, commercial and private banking and marketspecific investment products such as RQFII quota required to purchase Chinese securities. These activities are first approved by Chinese financial authorities and then undertaken by Chinese, British and international banks, law firms and asset managers. These financial institutions are supported through UK financial authorities including the Bank of England, HM Treasury and the London Stock Exchange. Grasping how London's RMB market developed requires a detailed understanding of the characteristics, practices and relations of these financial institutions and policymakers. Using snowball sampling, in-depth personal interviews were chosen as the predominant form of inquiry to investigate such micro-level factors. Interview questions were divided into two sub-sections. The first section investigated the policy motivations and external environment that gave impetus to the RQFII scheme in the context of RMB internationalisation. The second section explored the specific role that London plays in this process relative to other offshore RMB centres.

This study faced two challenges: untangling the cross-cultural nature of RMB networks in London, and tracing their evolution over time. To ensure the validity of findings across geographical contexts and time horizons, the method of triangulation was applied. This study draws on an original dataset of 121 multi-stakeholder interviews carried out in London and China's main financial and political centres, that is, Beijing, Shanghai, Hong Kong and Shenzhen. This dataset covers a period of three years, which spans the year of London's RQFII approval in 2013 until 2015. This enabled us to 
account for shifts in attitudes and decision-making over an extended time horizon and across geographical locations. In China, 75 elite interviews were carried out. These focused on officials from the main R/QFII administrative authorities, namely the Securities Regulatory Commission (CSRC), State Administration of Foreign Exchange (SAFE) and People's Bank of China (PBOC). Relevant offshore counterparts in Hong Kong included the Securities and Futures Commission (SFC) and Hong Kong Stock Exchange (HKSE).

To gauge the extent to which RMB finance has been integrated into London, 46 interviews were conducted with London-based executives from Chinese and non-Chinese financial services institutions. These included banks involved in RMB trading and China-dedicated practice groups of securities law firms. Follow-up interviews were carried out with the aforementioned respondents in China and London. This allowed for longitudinal comparison of policy motivations and private sector attitudes towards the role of RMB finance in London's IFC development.

Potential bias may nonetheless be introduced, as some regulators and financial institutions may strategically downplay or hide political interference. To ensure the robustness of findings, responses from Chinese political elites were triangulated with responses from other important stakeholder groups. These included the Stock Exchange Committees in Shanghai (SHSE) and Shenzhen (SZSE) and government think-tanks such as the Institute of World Economics and Politics (IWEP). Similarly, financial sector interviews in London were verified against responses from the Bank of England (BOE) and UK Treasury, which oversee the City's RQFII hub. These multistakeholder interviews were cross-checked against Chinese and English news sources including South China Morning Post, Xinhua and Financial Times, and official documents from PBOC, SAFE and CSRC. UK equivalents included policy reports from the UK Treasury and National Office for Statistics. Overall, this triangulation methodology minimised the interpretational freedom of interview responses across cultural contexts and allowed for reconstructing how London's RMB centre evolved over time. 


\section{Results and Discussion: Contextualising London's first-mover advantage}

Before examining London's development path as an RMB centre, it is necessary to contextualise its creation, by analysing the decision-making process behind its initial selection as the first RMB hub outside Asia. This provides an important foundation for understanding what drives the uneven geographical distribution of offshore RMB centres.

The 2008 global financial crisis triggered a paradigm shift in Chinese policy attitudes. It eroded the legitimacy of the Anglo-American financial model and strengthened the view across the spectrum of Chinese elite opinion that the notion of 'free markets' is a 'Western trap' to undermine Chinese sovereignty (Kirshner, 2014). China's over-reliance on the US dollar resulted in excessive exposure to global liquidity crises, which undermined trade finance (SAFE, personal interview, April 2014). Such spill-over effects were a key concern for the Chinese party leadership since sustained economic growth continues to depend on trade. It is against this backdrop that the Chinese authorities decided to develop the RMB into a global reserve currency to reduce dependency on Western markets and thus maintain financial stability in the long-run (PBOC, 2009). Capital market reforms such as the launch of the RQFII scheme in 2011 provided a central link to achieve this objective. Creating incentives for foreign investors to hold RMB-denominated assets would boost the inflow of RMB into domestic capital markets and thus promote the use of RMB in international transactions (PBOC, personal interview, June 2014). The advent of the RQFII scheme should therefore be understood from the perspective of externally induced shifts in Chinese political choices. A global offshore RMB market provided a strategic tool to leverage domestic capital market development for the purpose of RMB internationalisation and thus ensure stable economic growth.

Initially, the RQFII programme was only open to Hong Kong-based subsidiaries of Mainland Chinese firms. This provided Chinese policymakers with a regional testing ground for RMB 
internationalisation (SZSE, personal interview, June 2014). Given its de facto role as China's offshore financial centre, Hong Kong has by far the largest deposits of RMB outside Mainland China (HKMA, 2015). It was thus the obvious choice in geographical location to experiment with the development of the RMB offshore market in a controlled regional setting. This is also reflected in the RQFII quota allocation, as Hong Kong still holds the single largest quota volume granted to any IFC (Figure 1). In 2013, the Chinese authorities extended the RQFII scheme to all foreign investors, providing that these are domiciled in Hong Kong. This clarifies that the home bias in selecting RMB centres has an inclusive effect: What mattered is not a firm's country of origin but its chosen geographical location. The necessity for foreign investors to register their entities in Hong Kong to access RMB assets was designed to reinforce Hong Kong's location-specific competitive advantage over other IFCs (HKSE, personal interview, May 2014). Hong Kong's close relational proximity to Mainland China therefore translated into a powerful resource for establishing itself as the main RMB gateway under the 'one country, two systems' framework.

Given the policy emphasis on controlled regional experimentation, the subsequent expansion of the RQFII scheme is perplexing. London was chosen to become the world's first foreign RMB centre, even outcompeting regional Asian competitors such as Singapore, Seoul and Taipei (Figure 1). This clarifies that RMB deposits alone cannot explain which IFCs receive early RQFII approval. If that were the case, Taipei would have been chosen before London since Taiwan's RMB pools are only second to Hong Kong and far exceed those in Europe (Hsu, 2014).

Financial trading volumes offer a plausible explanation. Alongside New York, London continuously ranks top in this respect. To accelerate RMB internationalisation, it made sense for the Chinese government to leverage the financial power of these leading foreign exchange trading centres (SAFE, personal interview, April 2014). Yet, New York has thus far remained outside the club of offshore RMB centres. The exclusion of Taiwan and New York therefore suggests that there is another important variable at play, which trading volumes and RMB liquidity cannot capture. 
[Insert figure 1 here]

What unites the cases of Taiwan and New York is that the relations of their respective governments with China are relatively weak compared with the UK and Singapore. For example, Taiwanese relations with China have been tense since the 1949 Chinese civil war, due to which bilateral trade has suffered (IWEP, personal interview, November 2015). Chinese policymakers have therefore used RQFII access as a 'bait' to revive economic relations, by making Taiwan's RQFII approval conditional on its ratification of a Cross-Strait trade deal (RQFII-licensed bank, personal interview, November 2013). In light of anti-China protests, the Taiwanese government retreated from the trade deal, thus giving the Chinese government an excuse to put RQFII approval on hold (RQFII-licensed asset manager, personal interview, June 2014).

Similarly, New York is not among RQFII licence holders despite its status as a leading 24hour trading centre. According to Chinese policymakers, the 'US is not a destination for Renminbi [trading]' (CSRC, personal interview, April 2014). In fact, it conflicts with China's policy goals to reduce dependency on the US dollar in trade finance. Reciprocally, the political appetite in the US for establishing an RMB centre is limited. One reason is that the American government has accused China of currency manipulation, thus straining Sino-US relations (SFC, personal interview, May 2014). Furthermore, the RMB is seen as a viable alternative to the US dollar as a reserve currency (RQFII-licensed bank, personal interview, April 2014). The cases of Taiwan and New York therefore demonstrate that bilateral tensions between China and an IFC's respective home government have an exclusionary effect on securing privileged RMB hub status.

In contrast, London's strategy of nurturing relational proximity with Chinese policymakers paved the way for its first-mover advantage in the offshore RMB network. Whilst London received RQFII status in 2013, the UK government had been pushing for RMB rights long beforehand. These aspirations were rooted in the context of the 2008 crisis, which clarified that staying competitive in 
the global IFC landscape required London to enter new markets (London-based investment bank, personal interview, June 2015). As part of this reorientation strategy, the City turned to RMBdenominated trading alongside other newly emerging forms of financial services provision including Islamic finance (Bassens et al 2010) and climate finance (Knox-Hayes, 2013). To exploit the opportunities afforded by RMB finance, policymakers and financial professionals alike were keen to develop London's capabilities as a leading RMB centre (London-based securities law firm, personal interview, February 2015). These objectives matched China's strategic interests of expanding the RMB's use in international payments to overcome its limited convertibility (IWEP, personal interview, April 2014).

High-profile state visits provided an important tool to cultivate close relations and mutual policy agendas. For example, the Chinese vice-premier was invited to visit the UK in September 2011, after which a joint plan was announced to transform London into a leading RMB centre (BOE, personal Interview, November 2015). Sino-UK ties were further strengthened when the British Chancellor of the Exchequer announced that London would launch a forum with the Hong Kong Monetary Authority to promote RMB-denominated trade (HM Treasury, 2012). British banks and financial institutions backed this policy agenda. They urged the UK Treasury to obtain RQFII status to secure a major share of what they viewed as a rapidly growing market in foreign exchange and bond issuance (HM Treasury, personal interview, November 2013). This alignment of public-private interests on RMB finance was a decisive enabling mechanism for relational proximity with Chinese leaders, which helped secure RQFII privileges for London ${ }^{\text {vii }}$.

Similarly, strategic gains for China and the UK were reciprocal. In exchange for RQFII hub status, Chinese policymakers were able to negotiate better investment conditions in overseas markets including for its sovereign fund (RQFII-licensed Chinese asset manager, personal interview, April 2014). According to an official at the Hong Kong Stock Exchange, 
'It is all about exchanging policy gifts. London got the first RQFII hub beyond Hong Kong. In return, the British government has agreed to start talks to allow Chinese banks to set up wholesale units in the UK' (personal interview, April 2014).

The creation of London's RMB hub and, by extension, the geographical distribution of RMB offshore centres, is thus best understood as an interdependent foreign policy game. UK and Chinese policymakers exchange resources they each require, whereby RQFII status represents the 'golden carrot'. Successful approval depends on whether an IFC and the regulatory regime within which it is embedded can supply the Chinese government with the resources it requires to promote RMB internationalisation.

Location-specific advantages also contributed to London's first-mover advantage. For example, as its time zone bridges the US, Europe and Asia, London accounts for 40 percent of global foreign exchange dealings, trading more dollars than New York and more euros than all of Europe combined (CityUK, 2015). This dominant position in currency markets is reflected in London's highly skilled and internationally diverse labour force in the banking sector. London is a 'genuine international financial centre - it dominates in forex [foreign exchange] markets and is much more outward looking than New York' (London-based Chinese bank, personal interview, March 2015). This competitive edge in servicing international markets dates back to London's pioneering role in developing Euro currency markets in the 1950s (Burns, 1999). Combined, this unique blend of institutional features provided both the resources needed for China's closer financial integration with the West and an ideal launch pad for RMB internationalisation (PBOC, personal interview, March 2014). This is reflected in several policy decisions: For one, the Chinese government selected London as the first IFC to issue an RMB-denominated bond outside China in 2012. Furthermore, it allocated RMB 80 billion in RQFII quota to London, thus outcompeting regional Asian competitors such as Singapore. Other leading money centres such as New York were considered to lack 
'the historic emphasis on foreign exchange markets [...]. There isn't the political appetite to work together [with Beijing] and London has a much longer commercial history with China, particularly through Hong Kong. [Compared to New York] this makes [London] a much more attractive RMB proposition (Chinese securities law firm, personal interview, March 2015).

In sum, the evidence highlights that an IFC's ability to leverage its financial capital and knowledge pools in RMB markets is conditioned by an inter-dependent exchange of resources with the Chinese state. In essence, RMB internationalisation is an economically driven process. But the political dividends of securing RQFII status are reserved to those money centres whose home jurisdictions have cultivated strong bilateral relations with China. Without such ties, an IFC is unlikely to secure RQFII approval even if it pools financial and knowledge-specific resources that the Chinese government desires. Accordingly, London was able to secure first-mover advantages because it offered a bundle of resources in direct support of RMB internationalisation, which its competitors were unable to offer.

\section{Selective Adaptation over Integration: London's RQFII experience}

To understand the subsequent development of London's offshore RMB centre, it is necessary to look beyond UK and Chinese policy motivations and examine the City's internal adaptation process. This section shows that resistance among London's private sector vis-à-vis China's prescribed path of RMB internationalisation changed the nature of private-state bargaining dynamics, which resulted in the selective adaptation of the City's financial architecture to RMB finance. Two main manifestations of selective adaptation stand out and warrant further analysis: the demand for RMB-denominated securities among London's fund managers and the development of Chinese financial institutions within the City's local market structures. Each of these features is discussed in turn.

State capitalism versus private interests: Market demand for RMB-denominated assets 
Although UK policymakers have expressed strong commitment to London's RMB centre development, private sector appetite for RMB-denominated investment products has been limited. This discrepancy can be explained by fluctuations in Sino-UK relations and the effect this had on expectations among London's financial community. For example, in April 2012, the UK government decided to host the Dalai Lama in London, which was viewed as a significant 'faux pas' by Chinese authorities (RQFII-licensed Chinese asset manager, personal interview, June 2015). The political relations between the UK and China 'froze' as a result (Chinese securities law firm, personal interview, March 2015). This effectively stalled London's development as an offshore RMB centre throughout the remainder of 2012. This situation generated considerable uncertainty within London's financial sector about the City's future role in RMB internationalisation. Consequently, asset managers turned towards more stable Asian currency markets such as Japan and Korea, which undermined the demand for RMB-denominated assets (RQFII-licensed investment bank, personal interview, December 2015).

To break the political deadlock and stimulate investment appetite for RMB investments, UK policymakers mobilised London's financial sector as a foreign policy tool rather than relying on foreign office discussions. For example, in February 2013, the UK central bank governor visited his Chinese counterpart to discuss London's future in offshore RMB finance. This meeting culminated with the UK being granted the privilege to launch an RMB-sterling currency swap line as the first G7 country (BOE, personal interview, November 2015). These agreements are a key element of China's RMB strategy, as they facilitate deeper financial and monetary integration with the signatory countries (PBOC, 2011). Another state visit to China followed shortly afterwards, in October 2013, where the British Chancellor of the Exchequer granted Chinese banks the privilege to establish wholesale branches in the UK (HM Treasury, personal interview, November 2013). These policy moves highlight the shift in the UK's bargaining position: Maintaining a head start in the growing 
offshore RMB market was dependent on adapting London's regulatory infrastructure in line with Chinese demands and thus restore the relational proximity between UK and Chinese policymakers.

The City's private sector community, however, did not share this willingness to adapt. This is because the positive stabilisation effect that closer Sino-UK bilateral relations had on investor confidence was undermined by increased volatility in RMB currency markets (RQFII-licensed bank, personal interview, November 2013). Since 2009, the RMB had a virtual peg to the US dollar, which led many investors to bet on its appreciation (RQFII-licensed asset manager, personal interview, June 2014). However, this trend came to a halt for two main reasons: first, in 2014, the US central bank ended its bond-buying programme aimed at lowering long-term interest rates, thus putting depreciation pressure on the RMB. Second, the Chinese government intensified this depreciation with three consecutive currency devaluations in 2015. This weakened the RMB's value by over three percent (SHSE, personal interview, December 2015). These policy moves triggered a rush to invest in non-RMB funds as investors who had previously bet on RMB appreciation suffered considerable losses (RQFII-licensed asset manager, personal interview, December 2015). Consequently, this dampened the appetite for RMB-structured products, as the stable interest rate differentials to invest in such products were effectively wiped out (RQFII-licensed bank, personal interview, December 2015). Paradoxically, this also undermined Beijing's efforts to accelerate RMB internationalisation, by eroding confidence in the RMB as an investment currency and store of value.

The low demand for RMB-denominated investments is best illustrated by the stagnation in RQFII quota and RMB flows passing through London in the wake of RMB volatility. Initially, the City's RQFII quota of RMB 80 billion exceeded that of Asian competitors including Singapore and Korea, with RMB 50 billion each. However, the latter both received quota top ups of 50 percent and 100 percent respectively, whereas London received none (Figure 2). This decision reflects the fact that demand for RQFII quota has been lowest in London among top-ranked RMB hubs. Both the overall quota allocation and their distribution across investor types illustrate this well (Figure 2). What 
explains this leap forward by Singapore and Seoul is regional trade finance, which has been the main driver behind the demand for RQFII quota (SAFE, personal interview, April 2014). Although RMB volatility depressed quota demand worldwide, regional trade finance provided Singapore and Seoul with a buffer, since both are located in places with strong trade links to China.

[Insert figure 2 here]

RMB trading activity reveals a similar pattern. In 2014, Singapore overtook London as the top foreign IFC location for processing RMB payments: Its share of total offshore RMB trading flows increased to 6.8 per cent, whereas London accounted for 5.9 per cent (SWIFT, 2014). Processing trade payments with Asian neighbours using Chinese currency has provided a 'regional testing ground' to experiment with RMB internationalisation (SZSE, personal interview, June 2014). Unlike London, Singapore's location in Southeast Asia, and its sizable build-up of RMB deposits, enable it to support China's regional trade as the largest foreign exchange centre for Asian currencies (RQFII-licensed asset manager, personal interview, June 2014). Market-driven features such as RMB deposits may thus not determine which IFCs receive early RQFII approval but they do play a vital role in shaping which IFCs get ahead in the subsequent development of offshore RMB business. London's relatively slower development therefore highlights an expectations-capabilities gap between the policy agenda for its role in RMB internationalisation and what can realistically be achieved without support from the private sector. Relational proximity between governments may go a long way in helping IFCs secure first-mover advantages in RMB finance but it does not guarantee their endurance.

The evidence suggests that the development of offshore RMB centres needs to be understood as a two-fold sequencing process: Whereas the initial creation of RMB hubs is largely the result of intergovernmental bargaining, much of their subsequent development depends on the successful 
alignment of politics and economics. The key arbiter in determining if offshore RMB markets develop is whether the private sector can identify and satisfy any underlying demand for RMB assets (BOE, 2012). The demand for RMB-denominated trade finance in East Asian markets therefore explains why IFCs in this region were able to overtake London, where the appetite for RMB securities remained relatively low. This point is instructive, as it suggests that location matters considerably in offshore RMB finance: Those IFCs situated within close geographical proximity to China benefit from the positive economic spill-over effects that inter-regional trade has on RMB markets.

State capitalism versus private interests: Chinese commercial banks in London

The selective adaptation of London's financial architecture to RMB finance is also visible in the extent to which Chinese commercial banks are incorporated into the domestic labour market. Before 2014, Chinese banks could only open subsidiaries rather than branches in London (London-based Chinese bank, personal interview, March 2015). This reflected the cautious and risk-adverse approach of UK regulatory authorities towards foreign banks following the 2008 financial crisis. Bank subsidiaries were favoured because they have more stringent liquidity and capital requirements compared to bank branches (BOE, personal interview, November 2015). This need to operate as tightly supervised subsidiaries made it difficult for Chinese banks to expand (London-based Chinese bank, personal interview, April 2015). In turn, this threatened London's status as the leading Western RMB hub.

To avoid losing this position, the UK government engineered a policy U-turn, by permitting Chinese banks to operate as branches instead. The Industrial and Commercial Bank of China was the first Chinese bank to be granted a UK bank branch licence in 2014. These branch licenses enabled Chinese banks to better exploit the resources of their home lenders and move supervision to Beijing 
authorities (London-based Chinese bank, personal interview, April 2015). Furthermore, the China Construction Bank was granted approval to open Europe's first RMB clearing bank in London. Although the bank also started trading in Paris and Frankfurt later on, it made London its European headquarters (Fleming and Parker, 2014). This underscores that mutual political interests served as an initial enabling mechanism for inserting Chinese banks into London's IFC architecture.

Successful institutional insertion does, however, not equate to successful institutional integration. Whilst all four of the largest Chinese state-owned banks have now established local branches, their development within London is hampered by their limited engagement with the City's labour force. This is reflected in their staffing policies, which are subject to strict controls by the Chinese government. In line with government requirements, Chinese offshore entities are managed by secondees from Mainland China rather than by local professionals (London-based Chinese bank, personal interview, March 2015). This is partly due to the so-called 'party supervises the cadre' rule (Dang Guan Ganbu) according to which the Chinese Communist Party appoints top managers in state-owned enterprises (Gong, 2014). Internal management appointments and career progression are all strictly controlled by party agencies rather than determined by market demand (IWEP, personal interview, April 2014). Consequently, this highlights the clash between the state-led labour market practices of Chinese banks and the market-led labour market standards within the City of London.

This clash poses three main challenges for Chinese commercial banks operating in London. First, their rigid staffing policies impede the successful integration into London's IFC infrastructure. Second, these same staffing policies prevent the stimulation of market-led incentives. Secondees are more focused on 'managing their own careers [at home] rather than taking risks and making new business opportunities in London' (London-based Chinese bank, personal interview, March 2015). Third, and as a direct consequence of the previous two points, Chinese financial institutions remain cut off from the pool of financial expertise and specialist financial services concentrated in the City. According to the head of the China practice group at a London-based securities law firm, 
'the reliance on Chinese talent is an issue [for Chinese banks in London] as there remains a lack of overlap between domestic and Chinese labour markets and this isn't helping educate the wider market into the process of RMB internationalisation, London's role within it and the opportunities for market participants that might exist' (personal interview, March 2015).

This clarifies that the regulatory grip over Chinese banks undermines their responsiveness to market needs and thus their ability to connect with financial knowledge flows in London. Consequently, this prevents their offshore operations from integrating effectively into London's financial architecture, which Chinese policymakers had set out to achieve. These restrictions highlight that the Chinese party-state was not only a major enabling force behind London's RQFII hub; ironically, it also acted as a 'brakeman', by prioritising state control over market demands. This exposes an inherent paradox in China's RQFII strategy: Without letting market forces play a greater role in determining staffing policies, it will thus be difficult for Chinese financial institutions to fully leverage London's locational advantages as a resource for RMB internationalisation.

\section{Conclusion}

This paper sought to explain the uneven development of London's RMB trading centre. The City of London was the first foreign IFC approved by the Chinese government to become an offshore RMB centre. Despite this first-mover advantage, its subsequent development was hampered by the City's selective adaptation to RMB finance, thus forfeiting its position as the largest offshore RMB hub outside Hong Kong. The findings show that this puzzling shift from first-mover to relative laggard can be explained by tracing how state and private sector interests co-evolved over time. Mutually reinforcing interests facilitated close relations between Chinese and UK policymakers, which enabled 
London to become the first foreign offshore RMB hub. However, state-private sector interests started to diverge over the subsequent development of London's RMB business. This was underpinned by financial sector's limited appetite for RMB-denominated assets and the insufficient integration of Chinese banks into the City's labour market. Combined, these factors led to the selective absorption of RMB finance into London's financial architecture. This was not only reflected in the underallocation of RQFII licences; it also caused London's share of the offshore RMB trading market to fall behind other money centres.

These findings provide important insights for the IFC literature, by extending the focus beyond structural IFC complementarities such as knowledge and labour flows (Hall, 2010; Wójcik, 2013). As the results demonstrated, it was the constant ad hoc bargaining between state and private agents with competing interests that explained the uneven development of London's RMB hub. This suggests that the ideas of agents about political and economic outcomes matter considerably for the evolution of RMB centres. Rather than focusing on IFC complementarities, future research should therefore delve deeper into the politics of change behind IFC development.

The findings highlight that the role of states in offshore finance is multi-dimensional rather than singular: the Chinese government not only regulates and stabilises offshore RMB centres; it actively creates and expands them to achieve its objective of building a global offshore RMB market. Similarly, the UK government was as a decisive enabling force behind London's first-mover advantage, by cultivating close relations with Chinese policy elites. By specifying these variegated roles of the state, this paper extends the focus on the state's regulatory function in the offshore finance literature. It also lends empirical support to existing claims within this literature that 'offshore' transactions can occur in places typically considered to be 'onshore' money centre such as London (Clark and Monk, 2013).

Finally, this paper adds to debates in the global financial networks literature that the attraction of offshore finance stems from 'jurisdictional autonomy rather than being centres of finance 
professionals or expertise' (Clark et al, 2015: 244). This perspective suggests that, in offshore finance, IFC characteristics matter less than the nature of jurisdictions. The findings of this study suggest that this claim may not be universally applicable to all forms of offshore finance. Although important, finance-friendly laws and regulations within the subnational jurisdiction of the City of London are not the main determinant of its appeal in the case of offshore RMB finance. It was instead London's capacity to contribute to RMB internationalisation. In this endeavour, jurisdictional autonomy was less important. What mattered for Chinese policymakers was whether a place had strong political relations with China, a track record of foreign exchange expertise and a 24-hour bridging point to trade with East and West. These 'resources' supported Chinese efforts of creating a global offshore RMB market. The demonstrated centrality of financial centre characteristics in RMB offshore finance therefore calls for revising existing premises about the making of offshore finance.

At the policy level, the revealed tensions between state elites and London's financial sector clarify that the Chinese government can catalyse but not command offshore RMB markets outside its own jurisdiction. This is because, unlike Hong Kong, foreign RMB hubs such as London are not directly controlled by the Chinese party-state. From a policy perspective this is instructive, as it highlights that the emphasis on tight government control, in fact, undermines the creation of a global offshore RMB market. For Chinese policymakers, the success of RMB internationalisation will therefore depend on their political willingness to loosen their grip over capital markets including the recruitment policies of their financial institutions.

For foreign jurisdictions hosting RMB centres including Frankfurt or Luxemburg, this study highlights the conditional nature of growing offshore RMB business. The case of London revealed that strong inter-state relations are a crucial enabling condition behind the formation of new RMB hubs. Yet, shared policy interests between Chinese authorities and overseas governments are not a sufficient condition for their subsequent integration into existing IFC structures. The successful development of RMB business depends on securing private sector support at home. This requires 
foreign governments to adopt a more inclusive approach that is mutually beneficial for public and private sector agents alike. Without the continuous alignment of public-private interests, the development of RMB centres outside China will likely remain a tale of selective adaptation.

\section{Acknowledgments}

We would like to acknowledge the helpful comments made on an earlier version of this paper by Gordon Clark, Dariusz Wójcik and three anonymous referees. Any errors or omissions remain our own.

\section{Funding}

This work was supported by a British Academy Mid Career Fellowship awarded to Sarah Hall (MD130065) and grants awarded to Laura-Marie Töpfer by the UK Economic and Social Research Council (ES-J500112-1), the Royal Geographical Society (RGS-IBG Research Award) as well as the Clarendon Fund and Hertford College (Mann Senior Scholarship) of the University of Oxford.

\section{References}

Agnew, J. (2009). Globalization and Sovereignty, Lanham: Rowman and Littlefield.

Agnew, J. (2012). 'Putting Politics into Economic Geography', in Barnes, T., Peck, J. and Sheppard, E.(eds.) The Wiley-Blackwell Companion to Economic Geography, Chichester: Wiley.

Bank of England (BOE) (2012), ‘Three Principles for Successful Financial Sector Reform', Speech at 'City Week 2012: The International Financial Services Forum', Queen Elizabeth Conference Centre, London, 7 February.

Bassens, D., Derudder B. and Witlox, F. (2010). Searching for the mecca of finance: Islamic financial services and the world city network. Area, 42, 35-46. 
Bassens, D., Engelen, E., Derudder, B., \& Witlox, F. (2013). Securitization across borders: organizational mimicry in Islamic finance. Journal of Economic Geography, 13, 85-106.

Beaverstock, J., Hoyler, M., Pain, K. and Taylor, P. (2005). De-mystifying the Euro in European financial centre relations: London and Frankfurt, 2000-2001. Journal of Contemporary European Studies, 13, 143-157.

Burns, G. (1999). The state, the city and the Euromarkets. Review of International Political Economy, 6, 225-261.

Büthe, T. and Mattli, W. (2011). The New Global Rulers: The Privatization of Regulation in the World Economy NJ: Princeton.

Chen, Y., Henderson, V. and Cai, W. (2015). Political favouritism in China's capital markets and its effect on city sizes. Journal of Urban Economics, 1-19.

Chin, G. (2010). China's automotive modernization: The party-state and multinational corporations, Houndmills: Palgrave Macmillan.

CityUK (2015). Key Facts about UK Financial and Related Professional Services, London: City UK.

Clark, G. (2002). London in the European financial services industry: locational advantages and product complementarities. Journal of Economic Geography, 2, 433-454.

Clark, G., Lai, K. and Wójcik, D. (2015). 'Editorial Introduction to the Special Section:

Deconstructing Offshore Finance'. Economic Geography, 91, 237-249. 
Clark, G. and Monk, A. (2013). The scope of financial institutions: in-sourcing, outsourcing, and offshoring. Journal of Economic Geography,13, 279-98.

Coe, N., Lai, K. and Wójcik, D., (2014). Integrating Finance into Global Production Networks. Regional Studies, 48, 761-777.

Cohen, B. (2011). The Future of Global Currency: The Euro versus the Dollar, London: Routledge.

Cohen, B. J. (2015). Currency power: understanding monetary rivalry. Princeton: Princeton University Press.

Di Maggio, P., \& Powell, W. W. (1983). The iron cage revisited: institutional isomorphims and collective rationality in organizational fields. American Sociological Review, 48, 147-160.

Djelic, M.-L., \& Quack, S. (2007). Overcoming path dependency: path generation in open systems. Theory and Society, 36, 161-186.

Eichengreen, B. 2012. Exorbitant privilege: the rise and fall of the dollar Oxford, Oxford University Press.

Faulconbridge, J. (2004). London and Frankfurt in Europe's evolving financial centre network. Area, $36,235-244$.

Gong, B. (2014). Understanding Institutional Shareholder Activism: A comparative study of the UK and China, London: Routledge. 
Hall, S. (2010). Geographies of money and finance I: cultural economy, politics and place. Progress in Human Geography, 35, 234-245.

Hall, P. and Thelen, K. (2009). Institutional change in varieties of capitalism. Socio-Economic Review, 7, 7-34.

HM Treasury (2012). 'Chancellor announces further steps to promote the development of the RMB market in London', HM Treasury, 16 January: https://www.gov.uk/government/news/chancellorannounces-further-steps-to-promote-the-development-of-the-rmb-market-in-london (accessed 20 July 2015).

Hsu, S. (2014). 'The Expanding Offshore Renminbi' The Diplomat, 7 July, http://thediplomat.com/2014/07/the-expanding-offshore-renminbi/ (accessed 29 July 2015).

Hu, F. and Lin, G. (2013). Placing the Transformation of State-owned Enterprises in North-east China: The State, Region and Firm in a Transitional Economy. Regional Studies, 47, 563-579.

International Monetary Fund (IMF) (2015). 'IMF's Executive Board Includes Chinese Renminbi', $I M F, 30$ November, https://www.imf.org/external/np/sec/pr/2015/pr15540.htm (accessed 2 December 2015).

Johnston, M. (2015). The Chinese Devaluation of the Yuan. Investopedia, 2 September, : http://www.investopedia.com/articles/forex/090215/chinese-devaluation-yuan.asp (accessed 18 December 2015). 
Kirshner, J. (2014). American Power after the Financial Crisis by Jonathan Kirshner, Ithaca: Cornell.

Knox-Hayes, J. (2013). The spatial and temporal dynamics of value in financialisation: analysis of the infrastructure of carbon markets. Geoforum, 50, 117-128.

Kurdle, R. (2013). 'The future of offshore finance as a global policy problem', Presentation, Offshore Finance seminar, Oxford University, September 2-3, http://www.smithschool.ox.ac.uk/ events/Kudrle\%20Future\%20 of\%20Offshore \%20Finance\%20final.pdf.

Mundell, R. (1993). 'EMU and the International Monetary System: A Transatlantic Perspective', Working Paper 13, Vienna: Austrian National Bank.

Oh, S.-Y. (2013). Fragmented Liberalization in the Chinese Automotive Industry: The Political Logic behind Beijing Hyundai's Success in the Chinese Market. China Quarterly, 216, 920-945.

Organization for Economic Cooperation and Development (OECD) (2008). OECD Benchmark Definition of Foreign Direct Investment, Paris: OECD.

People's Bank of China (PBOC) (2011) Highlights of China's Monetary Policy in the First Quarter of 2011, Beijing: PBOC.

Society for Worldwide Interbank Financial Telecommunication (SWIFT) (2014). Singapore overtakes London as top RMB offshore clearing centre after Hong Kong. SWIFT, 28 April, https://www.swift.com/insights/press-releases/singapore-overtakes-london-as-top-rmb-offshoreclearing-centre-after-hong-kong (accessed 18 January 2016). 
Töpfer, L.-M. (2015). Capital market access in China: The role of power resources in global financial networks. Working Paper, Smith School for Enterprise and the Environment, University of Oxford.

Wainwright, T. (2011). Tax doesn't have to be taxing: London's 'onshore' financial industry and the fiscal spaces of a global crisis. Environment and Planning A, 43, 1287-1304.

Wei, D. (2015). Network Linkages and Local Embeddedness of Foreign Ventures in China: The Case of Suzhou Municipality. Regional Studies, 49, 287-299.

Wójcik, D. (2013) The Dark Side of NY-LON: Financial Centres and the Global Financial Crisis. Urban Studies, 50, 13, 2736-2752. 


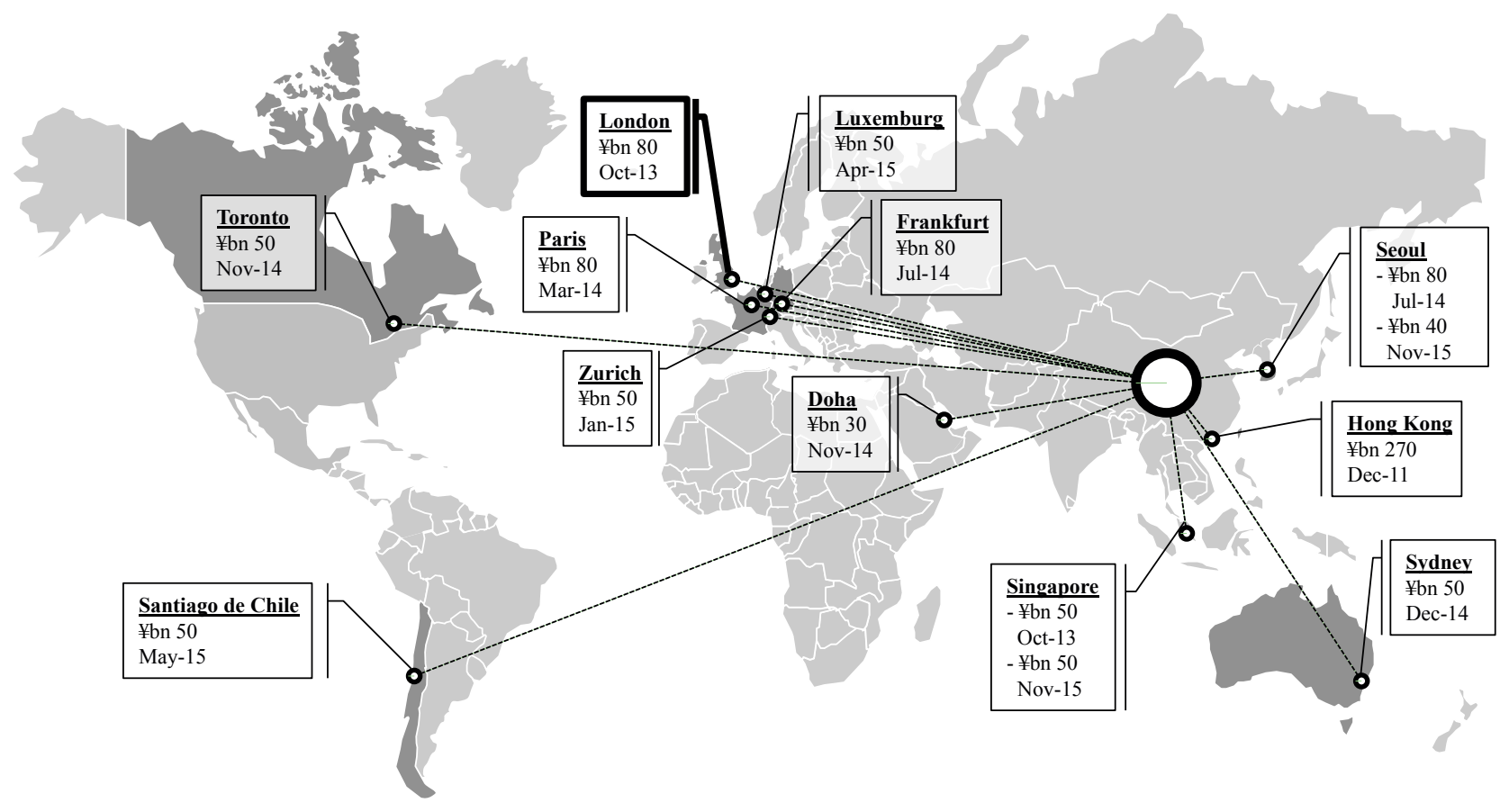

Source: Authors' own; figures from SAFE

Note: RQFII investment quota in ¥bn; RQFII licences by approval year 


\section{Figure 2: Distribution of RQFII quota across top RMB hubs ${ }^{\text {ix }}$ (RMB bn)}

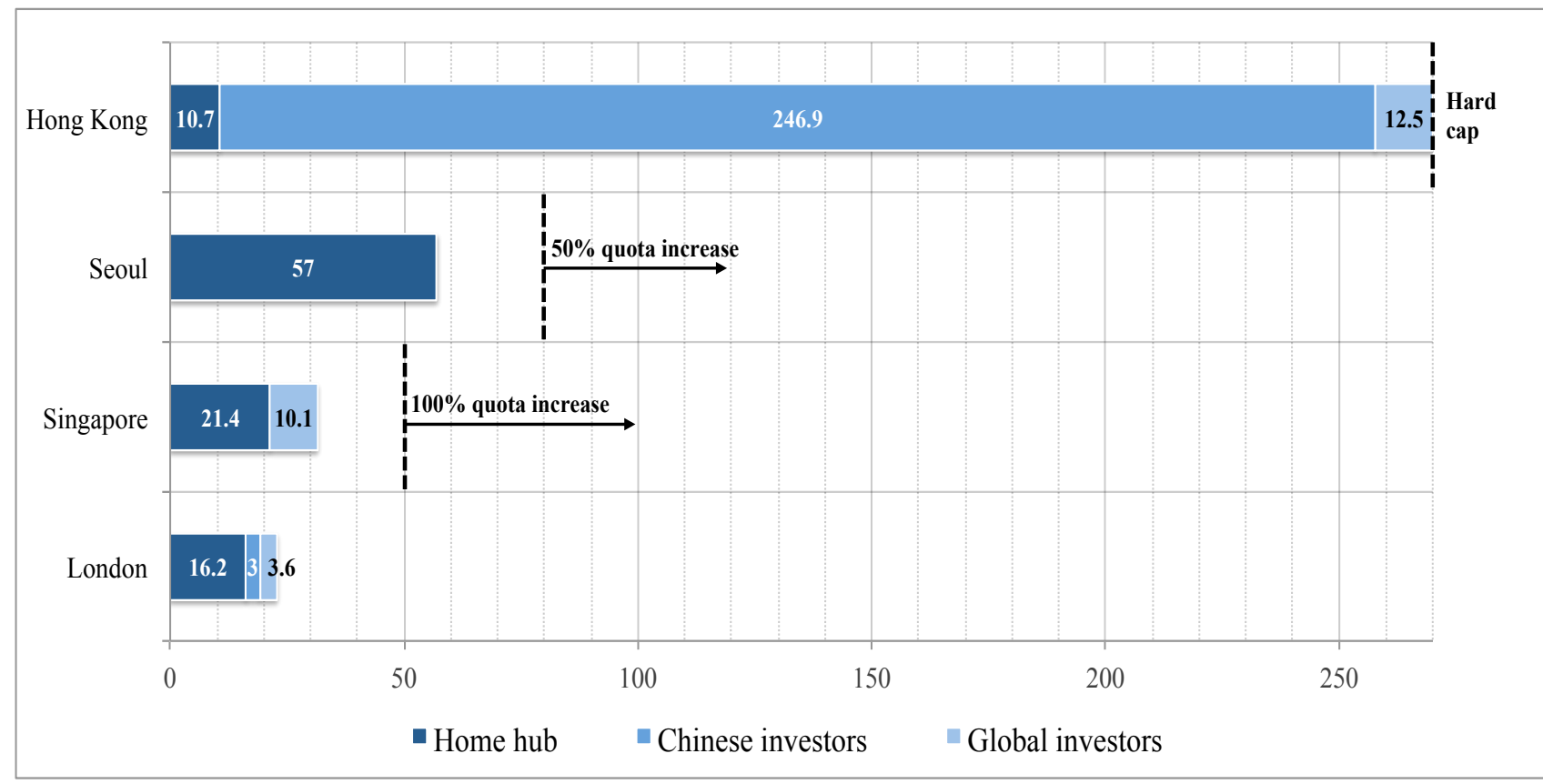

Source: author's own; based on Z-Ben (2015), CSRC (2015); SAFE (2015) 


\section{Endnotes}

\footnotetext{
${ }^{\mathrm{i}}$ Before 2004, RMB-denominated trading was not allowed outside of China.

ii Since Hong Kong is a special administrative region of the People's Republic of China, it is not treated as a 'foreign' offshore RMB hub.

iii Note that Hong Kong was the first offshore RMB centre established outside Mainland China. However, as a formal part of Chinese territory, the Mainland Chinese government directly shapes its institutional landscape. Given this special political status, Hong Kong does therefore not provide a template of 'organisational mimicry' for RMB centres located in Western contexts.

iv Financial globalisation is defined as the free movement of financial flows across national boundaries without restrictions, enabled by the international diffusion of liberalising measures (Büthe and Mattli, 2011).

'This paper defines 'institutions' as formal or informal norms, rules and enforcement mechanisms that are grounded in the common expectations between social agents and therefore guide their behaviour.

${ }^{\mathrm{vi}}$ Foreign indirect investments differ from foreign direct investments (FDI). In the case of FDI, the investor owns the assets himself and may thus exert a significant degree of control over the investee company. Investments typically count as FDI if an investor owns at least 10 percent of a firm's voting stock (OECD, 2008). In contrast, foreign indirect investments are made by foreign institutions that pool investor money to buy or sell financial assets in another country. Examples include investments by foreign mutual funds into stocks listed in another economy.

vii This is because the UK firm did not sell any of its own RQFII quota to provide the American company with access to RMB market. The transaction between the two parties did not involve the booking of financial instruments but merely the provision of financial advice. Consequently, this type of financial service would not classify as 'offshore finance' according to Kurdle's definition.

viii In addition to securing RQFII hub status in 2013, London was granted permission to set up the first Western RMB clearing bank, following a 2014 state visit by China's President.

ix Whether an IFC counts a 'top offshore RMB centre' is measured based on the respective volumes of both allocated quota allowance to the IFC and quota allocated to licensed investors.
} 